\title{
The Role of Nitric Oxide in the Maintenance of Vasoactive Balance
}

\author{
O. PECHÁŇOVÁ ${ }^{1,2}$, F. ŠIMKO 3
}

${ }^{1}$ Institute of Normal and Pathological Physiology and Centre of Excellence for Cardiovascular Research, Slovak Academy of Sciences, Bratislava, Slovak Republic, ${ }^{2}$ CRC and Institute of Physiology, AS CR, Prague, Czech Republic, ${ }^{3}$ Department of Pathophysiology and Third Clinic of Medicine, Medical Faculty, Comenius University, Bratislava, Slovak Republic

\begin{abstract}
Summary
Endothelial dysfunction may be considered as the interstage between risk factors and cardiovascular pathology. An imbalance between the production of vasorelaxing and vasoconstricting factors plays a decisive role in the development of hypertension, atherosclerosis and target organ damage. Except vasorelaxing and antiproliferative properties per se, nitric oxide participates in antagonizing vasoconstrictive and growth promoting effects of angiotensin II, endothelins and reactive oxygen species. Angiotensin II is a potent activator of $\mathrm{NAD}(\mathrm{P}) \mathrm{H}$ oxidase contributing to the production of reactive oxygen species. Numerous signaling pathways activated in response to angiotensin II and endothelin-1 are mediated through the increased level of oxidative stress, which seems to be in casual relation to a number of cardiovascular disturbances including hypertension. With respect to the oxidative stress, the NO molecule seems to be of ambivalent nature. On the one hand, NO is able to reduce generation of reactive oxygen species by inhibiting association of $\mathrm{NAD}(\mathrm{P}) \mathrm{H}$ oxidase subunits. On the other hand, when excessively produced, $\mathrm{NO}$ reacts with superoxides resulting in the formation of peroxynitrite, which is a free radical deteriorating endothelial function. The balance between vasorelaxing and vasoconstricting substances appears to be the principal issue for the physiological functioning of the vascular bed.
\end{abstract}

\section{Key words}

Endothelial dysfunction $\bullet$ Hypertension $\bullet$ Nitric oxide $\bullet$ Angiotensin II $\bullet$ Endothelins $\bullet$ Reactive oxygen species

\section{Introduction}

An imbalance in the production of angiotensin II, endothelins, reactive oxygen species on the one hand and nitric oxide (NO), prostacyclin and endothelium- derived hyperpolarizing factor (EDHF) on the other hand plays an important pathogenetic role in hypertension and hypertensive end-organ injury (Noll et al. 1997, Šimko and Šimko 1999, Schiffrin 2002, Púzserová et al. 2007). Angiotensin II (Ang II) stimulates nicotinamide adenine 
dinucleotide phosphate (NADPH) oxidase in the endothelium, smooth muscle cells, and the adventitia of blood vessels to generate reactive oxygen species, supporting endothelial dysfunction, vascular remodeling, and inflammation. Upregulation of endothelin-1, growth factors, adhesion molecules, nuclear factor $-\kappa \mathrm{B}(\mathrm{NF}-\kappa \mathrm{B})$, and other inflammatory mediators, as well as increased breakdown of nitric oxide and uncoupling of nitric oxide synthase may be involved in the progression of vascular pathologies (Schiffrin 2002, Hamilton et al. 2002).

Hypertension is accompanied with functional and structural alterations in the number of systems and tissues. Cardiac hypertrophy, fibrosis enlargement, smooth muscle cell hypertrophy/hyperplasia, vascular remodeling, endothelial dysfunction, atherosclerosis and microalbuminuria rank among the most important changes (Pecháňová et al. 1999, 2006b, Bernátová et al. 2006; Cebová et al. 2006, Čačányiová et al. 2006) resulting ultimately in heart failure, renal insufficiency, myocardial infarction or stroke (Török et al. 2006, Šimko 2007) (Fig. 1). In this context, predominantly those antihypertensive agents are considered that beside blood pressure lowering also restore the humoral balance within the vascular wall.

Antihypertensive action may be exerted both on the level of resistance vessels and in the central nervous system, depressing the increased sympathetic tone which is one of the most powerful tool for blood pressure control. Similarly, nitric oxide does not play a role only as a peripheral relaxing factor but it is also involved in the central regulation of sympathetic tone (Kuneš et al. 2004, Zicha et al. 2006a). Thus, the balance between vasorelaxing and vasoconstricting agents in vasomotor centers seems to be crucial for the control of the sympathetic tone.

The aim of this review is to analyze the role of endothelium and nitric oxide in the maintenance of vasoactive balance under pathophysiological circumstances, hypertension particularly.

\section{Endothelium}

The endothelium serves not just as a barrier of the transvascular diffusion but is the largest endocrine organ in the body. Its autocrine and paracrine actions play a critical role in the regulation of blood flow, coagulation, leukocyte adhesion, and vascular smooth muscle cell growth. Furchgott and Zawadzki (1980) demonstrated that the relaxation of vascular smooth muscle cells in response to acetylcholine is dependent on the integrity of the endothelium. Endothelium-derived relaxing factor was identified as a free radical gas - nitric oxide (NO) (Palmer et al. 1987, Ignarro et al. 1987). NO generation by endothelial cells is in principle constitutive but may be stimulated by a variety of compounds, including acetylcholine, angiotensin II, bradykinin and many others (Lüscher and Vanhoutte 1988). NO is not the sole endothelium-derived vasodilator. Prostacyclin $\left(\mathrm{PGI}_{2}\right)$, another endothelium-dependent vasodilator, relaxes the underlying smooth muscle cells through activation of adenylate cyclase and subsequent generation of cAMP. Constitutively released $\mathrm{PGI}_{2}$ (Moncada et al. 1976) appears to be involved in the regulation of resting vascular tone. $\mathrm{PGI}_{2}$ is released in higher amount in response to ligand binding on the cell surface such as thrombin, arachidonic acid, histamine, or serotonin. Endothelium also generates a hyperpolarizing factor, which is suspected to be an arachidonic acid metabolite produced by cytochrome P450 (Komori and Vanhoutte 1990). Within the endothelium, the synthesis and degradation of adenine nucleotides takes place. These purines can influence vascular tone and platelet aggregation through variable purinoceptors. Adenosine may serve as a vasodilator and potent inhibitor of platelet aggregation through stimulation of adenylate cyclase (Burnstock 1990, Pecháňová and Babál 1993).

Under some pathophysiological circumstances, e.g. in atherosclerosis or hypertension, endotheliumderived vasoconstricting factors can be released and contribute to the paradoxical vasoconstrictor effects. Apart from the peptides endothelin and angiotensin II, other endothelium-derived vasoconstricting agents such as superoxide anions, vasoconstrictor prostaglandins, and thromboxane $\mathrm{A}_{2}$ have been postulated (Vanhoutte et al. 2005).

\section{Nitric oxide}

The discovery of endothelium-derived relaxing factor, nitric oxide, allowed formulation of a novel concept in the pathogenesis of hypertension involving a crucial role of endothelium and nitric oxide (Furchgott and Zawadzki 1980). NO is generated by NO synthases, a family of enzymes that convert the amino acid L-arginine to L-citrulline and NO. All NOS isoforms are homodimeric enzymes that require the same substrate (Larginine), cosubstrates (molecular oxygen, NADPH) and cofactors (FMN, FAD, tetrahydrobiopterin, heme) 


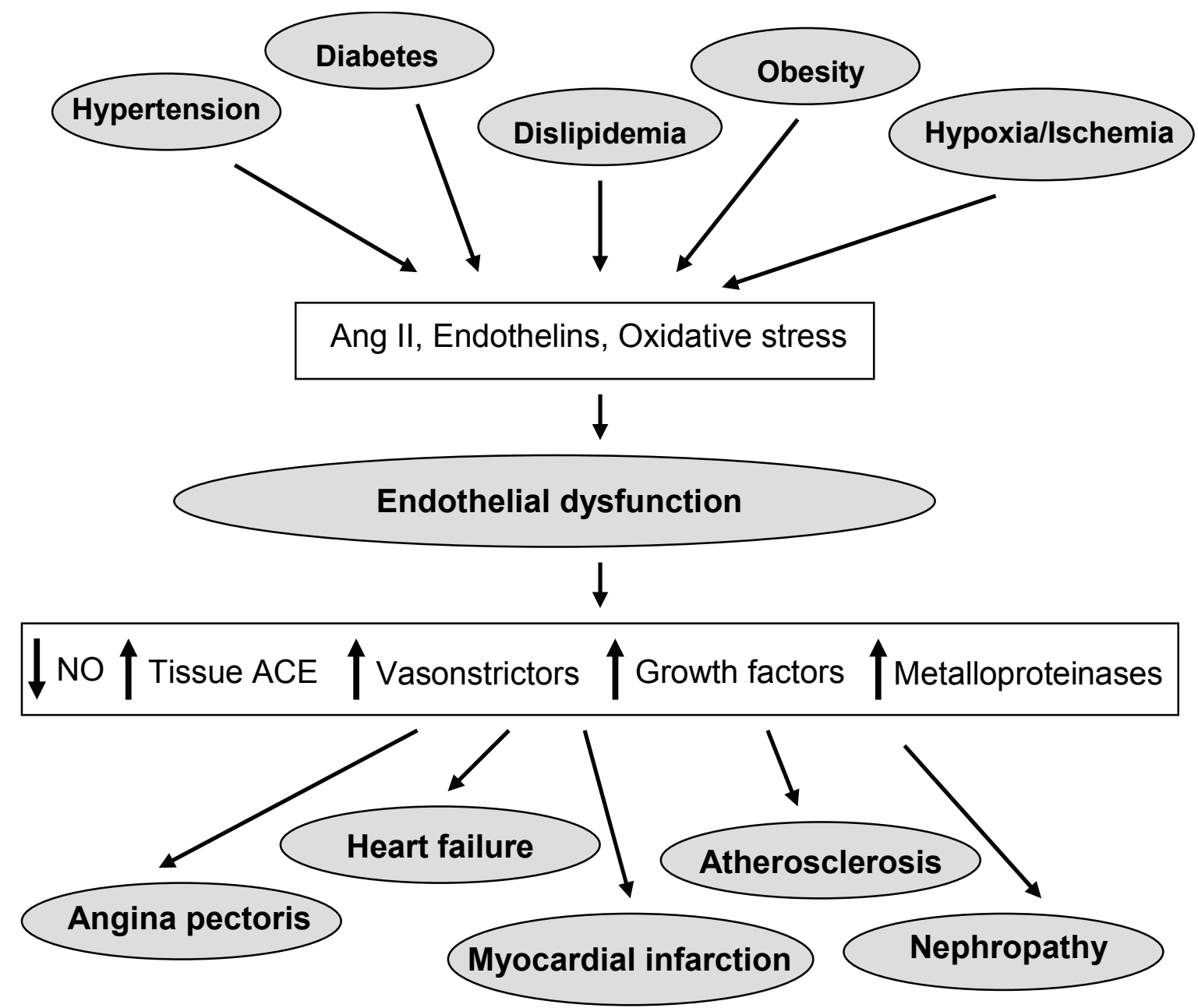

Fig. 1. Risk factors of cardiovascular diseases are associated with increased angiotensin II and endothelin production as well as with oxidative stress leading to endothelial dysfunction. Endothelial dysfunction can result in vascular abnormalities leading to the cardiovascular morbidity and kidney impairment. NO - nitric oxide; Ang II - angiotensin II, ACE - angiotensin converting enzyme

(Stuehr 1999). Four NOS isoforms have been described. They differ with respect to the main mode of regulation, the tissue expression pattern and the average amount of NO produced (Bernátová and Pecháňová 1998, Ghosh and Salerno 2003).

Endothelial NOS expressed in endothelial cells is the predominant NOS isoform in the vessel wall. Receptor-mediated agonist stimulation (e.g. bradykinin, acetylcholine, thrombin, histamine) leads to rapid enzyme activation by depalmitoylation, binding to calmodulin/calcium, displacement of caveolin and release from the plasma membrane (Govers and Rabelink 2001). In addition, shear stress is also an important modulator of eNOS activity. Endothelial NOS activity is also regulated at the transcriptional level because VEGF, insulin, bFGF increase eNOS expression while hypoxia and oxidized LDL decrease it (Sase and Michel 1997, Maxwell 2002). NO activates guanylate cyclase by binding to the heme moiety of this enzyme. Guanylate cyclase catalyzes the conversion of guanosine triphosphate (GTP) to cGMP, which in turn activates cGMP-dependent protein kinase. This kinase phosphorylates phospholamban, a regulatory protein for the $\mathrm{Ca}^{2+}$-adenosine triphosphatase (ATPase) in the sarcoplasmic reticulum. The $\mathrm{Ca}^{2+}$-ATPase decreases intracellular calcium concentration leading to smooth muscle relaxation (Sanders et al. 1995).

Except the vasorelaxing and antiproliferative properties per se, nitric oxide plays an important role in antagonizing the effects of Ang II, endothelins and reactive oxygen species.

\section{Angiotensin II}

Angiotensin II is a vasoconstrictor with the proliferative effect, involved in the regulation of salt and water homeostasis and pathological remodeling of the heart and vessels (Šimko and Šimko 1999). Ang II is a potent activator of $\mathrm{NAD}(\mathrm{P}) \mathrm{H}$ oxidase contributing to the 
production of reactive oxygen species which participate in variable pathologies within the circulation (Šimko and Šimko 1999, Hitomi et al. 2007).

NO antagonizes the effects of Ang II on vascular tone, cell growth, and renal sodium excretion, and also down-regulates the synthesis of ACE and Ang II type 1 receptors (Zhou et al. 2004). It has been shown that treatment with $\mathrm{ACE}$ inhibitor captopril prevents or reduces L-NAME-induced increase of blood pressure and heart hypertrophy (Bernátová et al. 1996, Pecháňová et al. 1997). Animals receiving simultaneously L-NAME and ramipril were also protected against development of hypertension and myocardial hypertrophy as well as against the deterioration of glomerular filtration rate and renal plasma flow (Hropot et al. 1994). Enalapril also inhibited development of both arterial hypertension and left ventricular hypertrophy in NO-deficient hypertension but failed to prevent ischemic myocardial lesions. This suggests that the renin-angiotensin system (RAS) plays a major role in the development of hypertension and cardiac hypertrophy, but its participation in ischemiainduced myocardial alterations is less probable in NOdeficient hypertension (Moreno et al. 1995).

It was shown previously that ACE inhibition upregulates eNOS expression. The mechanism of this upregulation is still unclear. However, it is conceivable that ACE inhibitor-induced accumulation of endogenous kinins mediates this effect (Morawietz et al. 2006). In L-NAME treated animals, the increased expression as well as activation of eNOS are masked by competitive NO synthase inhibitor. These results are in good agreement with the finding that captopril completely prevented development of hypertension and left ventricular hypertrophy due to the L-NAME treatment, but without affecting NO synthase inhibition (Pecháňová et al. 1997, Bernátová et al. 1999, Šimko et al. 2003). Captopril and enalapril also prevented blood pressure rise in young spontaneously hypertensive rats. Captopril, probably due to the antioxidant role of its thiol group, had more effective hypotensive effect than enalapril (Pecháňová 2007).

Ang II type 1 receptor blocker, losartan, prevented the development of L-NAME-induced hypertension and impairment of vascular relaxation to nitroprusside, isoprenaline, and cromakalim, vasodilators acting via the formation of NO, activation of betaadrenoceptors and opening of $\mathrm{K}^{+}$channels, respectively. Thus, losartan was able to improve both endotheliumdependent and -independent vascular relaxation.
Hyperpolarization of smooth muscle cells, increased sensitivity to $\mathrm{NO}$, and decreased oxidative stress in the vascular wall might participate on the protective effect of losartan (Kalliovalkama et al. 1999, Kitamoto et al. 2000).

\section{Endothelins}

The endothelin family consists of three structurally related peptides, ET-1, ET-2, and ET-3 (Kedzierski and Yanagisawa 2001). In the vasculature, the proendothelin may be released from the non-luminal surface of the endothelial cells and converted extracellularly to mature endothelin by membrane-bound endothelin-converting enzymes, which are neutral metalloproteinases. Endothelin does not appear to be stored in endothelial cells, but is synthesized de novo in response to several substances (thrombin, angiotensin II, cytokines) or physical stimuli (shear stress, hypoxia). Endothelin is a potent vasoconstricting agent with longlasting effects (Rubanyi and Botelho 1991).

There are numerous interactions between some of the vasoactive agents released from the endothelium. Many factors that stimulate endothelin synthesis, (e.g. thrombin, Ang II), also cause the release of vasodilators such as $\mathrm{PGI}_{2}$ and/or NO, which oppose the vasoconstricting action of endothelin. ET-1 also stimulates mitogenic activity on smooth muscle cells while $\mathrm{NO}$ and $\mathrm{PGI}_{2}$ inhibit this proliferative effect (Alberts et al. 1994).

It seems that the vascular reactions are the result of a complex interaction of many vasoactive pathways. The relative importance of these actions may vary in dependence to vascular beds, animal species or underlying pathological processes.

\section{Reactive oxygen species}

Reactive oxygen species (ROS) participate on physiological reactions by mediation of signal transduction. On the other hand, the excessive or inappropriate production of ROS may exert deleterious effects on the cardiovascular system resulting in the occurrence of hypertension, atherosclerosis and their consequences (Touyz and Schiffrin 2004). Most important radicals are superoxide anion $\left(\mathrm{O}_{2}^{-}\right)$, hydroxyl radical $(\mathrm{OH})$, and the reactive nitrogen species - nitric oxide and peroxynitrite $\left(\mathrm{ONOO}^{-}\right)$. A number of factors supporting the elevation of blood pressure such as Ang II, 


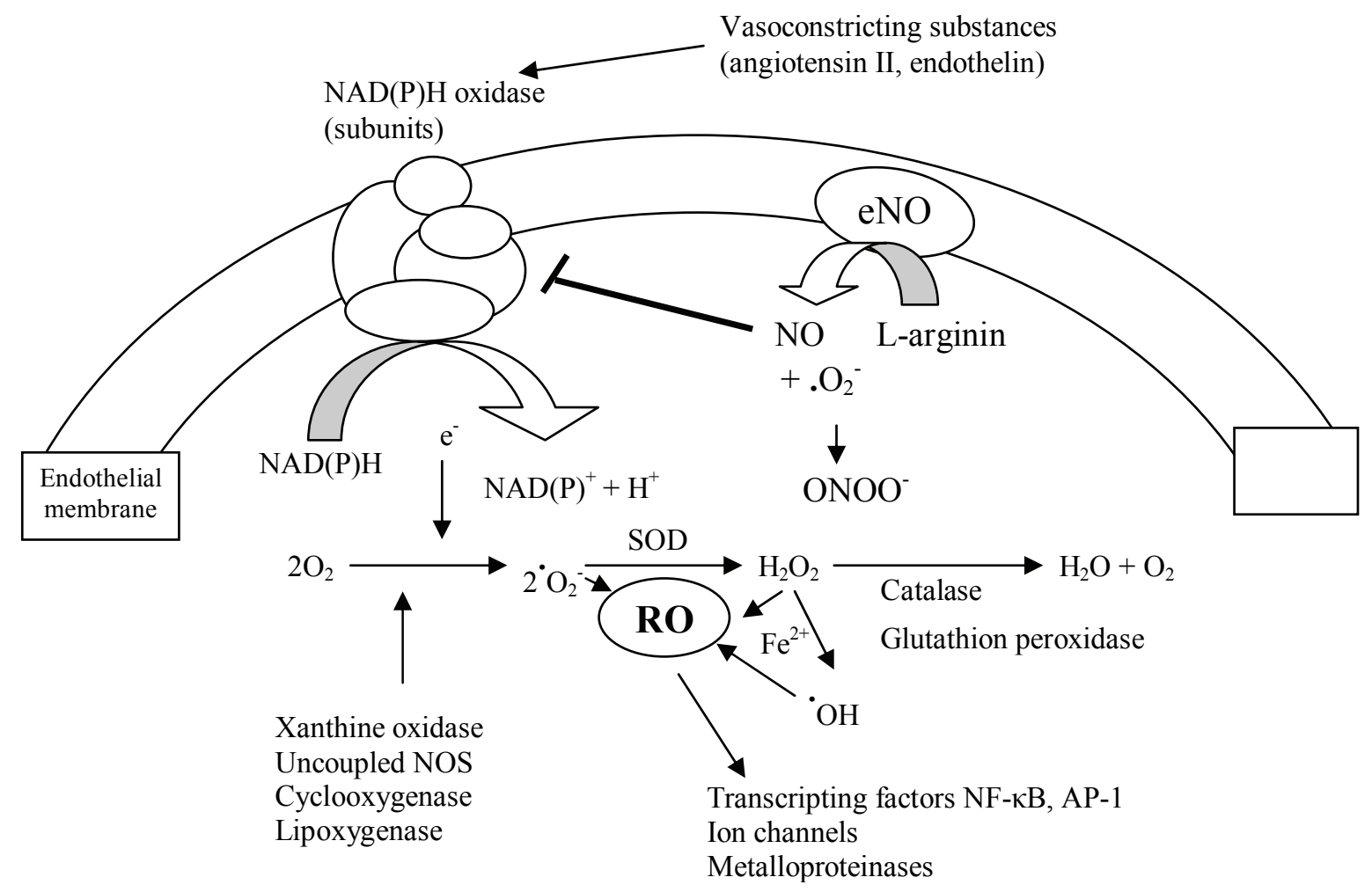

Fig. 2. Reactive oxygen species (ROS) generation in the cell. Vasoconstricting substances increase ROS production through $N A D(P) H$ oxidase, xanthine oxidase, uncoupled NO synthase, cyclooxygenase, lipoxygenase and mitochondrial respiratory chain enzymes. ROS generation activates nuclear factor NF-KB and activator protein 1 (AP-1), metalloproteinases and modulates intracellular $\mathrm{Ca}^{2+}$ concentration through ion channels alterations. Enzymatic systems, superoxide dismutase (SOD), catalase and glutathione peroxidase, are active in the defense against ROS by forming $\mathrm{H}_{2} \mathrm{O}_{2}$ and $\mathrm{H}_{2} \mathrm{O}$. Endothelial NO synthase (eNOS) produces nitric oxide (NO) which prevents association of $\mathrm{NAD}(\mathrm{P}) \mathrm{H}$ oxidase subunits. Concurrently, $\mathrm{NO}$ may, however, react with superoxides by forming peroxynitrites (ONOO-) with amplifying effect on endothelial dysfunction.

ET-1 or aldosterone stimulate ROS production through the activation of $\mathrm{NAD}(\mathrm{P}) \mathrm{H}$ oxidase, xanthine oxidase, lipoxygenase, uncoupled NO synthase, and mitochondrial respiratory chain enzymes. With respect to arterial hypertension development, $\mathrm{NAD}(\mathrm{P}) \mathrm{H}$ oxidase seems to be the main enzyme responsible for superoxide production (Lassegue and Griendling 2004) (Fig. 2).

Treatment with antioxidants was shown to decrease blood pressure, improve vascular function and structure and ameliorate target-organ damage in experimental as well as human hypertension (Lassegue and Griendling 2004, Púzserová et al. 2006). Antioxidant compounds, such as glutathione, vitamin $\mathrm{C}$, vitamin $\mathrm{E}$ and uric acid provide non-enzymatic protection against oxidative stress. Enzymatic systems represented by superoxide dismutase (SOD), catalase and glutathione peroxidase are active in the defense against ROS by forming $\mathrm{H}_{2} \mathrm{O}_{2}$ and $\mathrm{H}_{2} \mathrm{O}$. Finally, drugs inhibiting the neurohumoral activation also reduce the oxidative stress (Touyz and Schiffrin 2004).

In several models of animal hypertension blood pressure was reduced and vascular remodeling inhibited by consuming a diet rich in vitamin $\mathrm{C}$ or $\mathrm{E}$ (Chen et al. 2001). Moreover, SOD mimetic tempol, decreased blood pressure, vascular hypertrophy and improved endothelium-dependent relaxation (Chen et al. 2001, Kawada et al. 2002). Similarly, overexpression of SOD and catalase reduced blood pressure, improved availability of $\mathrm{NO}$ and endothelium-dependent relaxation in different models of hypertension (Chu et al. 2003). Apocynin, $\mathrm{NAD}(\mathrm{P}) \mathrm{H}$ oxidase inhibitor also prevented blood pressure elevation and cardiovascular hypertrophy in aldosterone-infused and spontaneously hypertensive rats (Park et al. 2004, Kojšová et al. 2006).

\section{Nitric oxide and maintenance of vasoactive balance}

About 20 years have passed since the discovery of NO. During this relatively short time period, our knowledge on the role of endothelium and nitric oxide in cardiovascular diseases have tremendously increased. It is generally admitted that the normal production of $\mathrm{NO}$ with its vasodilative, antiaggregative and antiproliferative 
action plays a crucial role in the maintenance of the physiologic conditions within the cardiovascular system.

L-arginine, a substrate for NO synthase, seems to be promising in preserving $\mathrm{NO}$ formation. However, L-arginine failed to prevent blood pressure increase and left ventricle remodeling due to chronic L-NAME treatment (Šimko et al. 2005). Some other effects of L-NAME, besides blood pressure increase and NO deficiency, could participate in this lack of L-arginine protection. It has been demonstrated that L-NAME inhibits L-arginine transport to the caveolae containing NO synthase (Maxwell 2002). Moreover, L-NAME increased the activity of nuclear factor- $\kappa \mathrm{B}$, which may participate in cardiovascular remodeling independently of the blood pressure increase (Pecháňová et al. 2004a).

As previously mentioned, ACE inhibitor captopril completely prevented NO-deficient hypertension, yet without improving NO synthase activity. It was suggested that both inhibition of Ang II formation and enhanced production of $\mathrm{PGI}_{2}$ caused by increased bradykinin level may be responsible for observed protective effect of captopril. In the regression experiment, three weeks of spontaneous recovery failed to reverse hypertrophy developed by L-NAME treatment, whereas captopril treatment reversed both hypertension and left ventricular hypertrophy (Bernátová et al. 2000). Captopril also reduced blood pressure, improved aortic relaxation and reduced heart and aortic remodeling in the hereditary hypertriglyceridemic rats (Šimko et al. 2002, Zicha et al. 2006b) and rabbits with aortic insufficiency (Šimko et al. 1997, 1998).

The thiol group might contribute to the benefits achieved by captopril. Thiols protect NO from oxidation by scavenging oxygen-free radicals and by forming nitrosothiols, both effects prolonging NO half-life and duration of NO action (Zhang and Hogg 2005, Pecháňová 2007, Sládková et al. 2007). Interestingly, aldosterone receptor blocker, spironolactone, was also able to prevent degradation of thiol groups and to increase the expression of endothelial NO synthase protein, the effects associated with blood pressure reduction (Pecháňová et al. 2006a, Török et al. 2007). It seems that not the absolute NO production but the relative balance between vasodilators and vasoconstrictors is decisive.

In our experiments, prevention of both blood pressure increase and cardiovascular remodeling by chronic treatment with antioxidant, provinol, was associated with increased NO synthase activity and enhanced expression of endothelial NO synthase
(Pecháňová et al. 2004a). It has also been documented that polyphenols of red wines strongly inhibit the synthesis of endothelin-1, a vasoactive peptide that is crucial for the development of coronary atherosclerosis (Corder et al. 2001). These data suggest that reduced oxidative stress due to antioxidant action of provinol, its ability to increase endothelial NO synthase activity and to decrease endothelin-1 synthesis may contribute to its antihypertensive effect and protection against cardiovascular remodeling in NO-deficient rats (Pecháňová et al. 2006b). Another antioxidant $\mathrm{N}$-acetylcysteine completely prevented L-NAME-induced hypertension, while its therapeutic effect in established L-NAME hypertension was only moderate, although this treatment restored NO synthase activity and lowered conjugated dienes in the heart and kidney (Rauchová et al. 2005). Similarly, in SHR chronic administration of Nacetylcysteine partially attenuated the blood pressure increase in young rats, while its effect was negligible in adult SHR with fully developed hypertension. Since chronic $\mathrm{N}$-acetylcysteine and also melatonin treatment had better preventive than therapeutic effects, it seems that ROS play a more important role in the induction than in the maintenance of hypertension. Therefore, the antioxidant treatment is expected be more efficient in the prevention than in the reduction of established hypertension (Pecháňová et al. 2006c, 2007).

In accordance with the hypothesis that nitric oxide plays an important role in the central regulation of sympathetic tone, we demonstrated that reduced $\mathrm{NO}$ production in the central nervous system of rats with L-NAME-induced hypertension is reflected by enhanced sympathetic vasoconstriction (Pecháňová et al. 2004b, 2006b, Kuneš et al. 2004, Zicha et al. 2006a). The balance between NO and angiotensin II in the vasomotor centers seems to play important role in the regulation of the sympathetic tone.

\section{Conclusions}

There is no doubt that endothelium plays a regulatory and protective role by generating vasorelaxing substances. However, under pathophysiological processes and circumstances endothelium-derived vasoconstricting factors can dominate and contribute to deleterious effects. Thus, the balance between vasodilating and vasoconstrictive substances appears to be inevitable for the maintenance of the physiological state of the circulation. Understanding the processes that regulate 
balance of vasoactive substances in peripheral vessels and central nervous system may result in more sophisticated approach to the treatment of hypertension and target organ damage.

\section{Acknowledgements}

This work was supported by the research grants VEGA 2/6148/26 and 1/3429/06 and APPV-0596-06.

\section{References}

ALBERTS GF, PEIFLEY KA, JOHNS A, KLEHA JF, WINKLES JA: Constitutive endothelin-1 overexpression promotes smooth muscle cell proliferation via an external autocrine loop. $J$ Biol Chem 269: 10112-10118, 1994.

BERNÁTOVÁ I, PECHÁŇOVÁ O, ŠIMKO F: Captopril prevents NO-deficient hypertension and left ventricular hypertrophy without affecting nitric oxide synthase activity in rats. Physiol Res 45: 311-316, 1996.

BERNÁTOVÁ I, PECHÁŇOVÁ O: NO synthase: biochemical properties and physiologic importance Bratisl Lek Listy 99: 474-482, 1998.

BERNÁTOVÁ I, PECHÁŇOVÁ O, ŠIMKO F: Effect of captopril in L-NAME-induced hypertension on the rat myocardium, aorta, brain and kidney Exp Physiol 84: 1095-1105, 1999.

BERNÁTOVÁ I, PECHÁŇOVÁ O, PELOUCH V, ŠIMKO F. Regression of chronic L-NAME-treatment-induced left ventricular hypertrophy: effect of captopril. J Mol Cell Cardiol 32: 177-185, 2000.

BERNÁTOVÁ I, BABÁL P, GRUBBS RD, MORRIS M: Acetylcholinesterase inhibition affects cardiovascular structure in mice. Physiol Res 55 (Suppl 1): S89-S97, 2006.

BURNSTOCK G: Dual control of local blood flow by purines. Ann N Y Acad Sci 603: 31-44, 1990.

ČAČÁNYIOVÁ S, CEBOVÁ M, KUNEŠ J, KRISTEK F: Comparison of vascular function and structure of iliac artery in spontaneously hypertensive and hereditary hypertriglyceridemic rats. Physiol Res 55 (Suppl 1): S73-S80, 2006.

CEBOVÁ M, KRISTEK F, KUNEŠ J: Differential remodeling of carotid artery in spontaneously hypertensive and hereditary hypertriglyceridemic rats. Physiol Res 55 (Suppl 1): S81-S87, 2006.

CHEN X, TOUYZ RM, RARK JB, SCHIFFRIN EL: Antioxidant effects of vitamins C and E are associated with altered activation of vascular NADPH oxidase and superoxide dismutase in stroke-prone SHR. Hypertension 38: 606-611, 2001.

CHU Y, IIDA S, LUND DD, WEISS RM, DIBONA GF, WATANABE Y, FARACI FM, HEISTAD DD: Gene transfer of extracellular superoxide dismutase reduces arterial pressure in spontaneously hypertensive rats: role of heparin-binding domain. Circ Res 92: 461-468, 2003.

CORDER R, DOUTHWAITE JA, LEES DM, KHAN NQ, VISEU DOS SANTOS AC, WOOD EG, CARRIER MJ: Endothelin-1 synthesis reduced by red wine. Nature 414: 863-864, 2001.

FURCHGOTT RF, ZAWADZKI JV: The obligatory role of endothelial cells in the relaxation of arterial smooth muscle by acetylcholine. Nature 288: 373-376, 1980.

GHOSH DK, SALERNO JC: Nitric oxide synthases: domain structure and alignment in enzyme function and control. Front Biosci 8: D193-D209, 2003.

GOVERS R, RABELINK TJ: Cellular regulation of endothelial nitric oxide synthase. Am J Physiol 280: F193-F206, 2001.

HAMILTON CA, BROSNAN MJ, AL-BENNA S, BERG G, DOMINICZAK AF: NAD(P)H oxidase inhibition improves endothelial function in rat and human blood vessels. Hypertension 40: 755-762, 2002.

HITOMI H, KIYOMOTO H, NISHIYAMA A: Angiotensin II and oxidative stress. Curr Opin Cardiol 22: 311-315, 2007.

HROPOT M, GROTSCH H, KLAUS E, LANGER KH, LINZ W, WIEMER G, SCHOLKENS BA: Ramipril prevents the detrimental sequels of chronic NO synthase inhibition in rats: hypertension, cardiac hypertrophy and renal insufficiency. Naunyn-Schmiedeberg `s Arch Pharmacol 350: 646-652, 1994.

IGNARRO LJ, BUGA GM, WOOD KS, BYRNS RE, CHAUDHURI G: Endothelium-derived relaxing factor produced and released from artery and vein is nitric oxide. Proc Natl Acad Sci USA 84: 9265-9269, 1987. 
KALLIOVALKAMA J, JOLMA P, TOLVANEN JP, KAHONEN M, HUTRI-KAHONEN N, WU X, HOLM P, PORSTI I: Arterial function in nitric oxide-deficient hypertension: influence of long-term angiotensin II receptor antagonism. Cardiovasc Res 42: 773-782, 1999.

KAWADA N, IMAI E, KARBER A, WELCH WJ, WILCOX CS: A mouse model of angiotensin II slow pressor response: role of oxidative stress. J Am Soc Nephrol 13: 2860-2868, 2002.

KEDZIERSKI RM, YANAGISAWA M: Endothelin system: The double-edged sword in health and disease. Annu Rev Pharmacol Toxicol 41: 851-876, 2001.

KITAMOTO S, EGASHIRA K, KATAOKA C, USUI M, KOYANAGI M, TAKEMOTO M, TAKESHITA A: Chronic inhibition of nitric oxide synthesis in rats increases aortic superoxide anion production via the action of angiotensin II. $J$ Hypertens 18: 1795-1800, 2000.

KOJŠOVÁ S, JENDEKOVÁ L, ZICHA J, KUNEŠ J, ANDRIANTSITOHAINA R, PECHÁŇOVÁ O: The effect of different antioxidants on nitric oxide production in hypertensive rats. Physiol Res 55 (Suppl 1): S3-S16, 2006.

KOMORI K, VANHOUTTE PM: Endothelium-derived hyperpolarizing factor. Blood Vessels 27: 238-245, 1990.

KUNEŠ J, HOJNÁ S, KADLECOVÁ M, DOBEŠOVÁ Z, RAUCHOVÁ H, VOKURKOVÁ M, LOUKOTOVÁ J, PECHÁŇOVÁ O, ZICHA J: Altered balance of vasoactive systems in experimental hypertension: the role of relative NO deficiency. Physiol Res 53 (Suppl 1): S23-S34, 2004.

LASSEGUE B, GRIENDLING KK: Reactive oxygen species in hypertension. Am J Hypertens 17: 852-860, 2004.

LÜSCHER TF, VANHOUTTE PM: Endothelium-dependent responses in human blood vessels. Trends Pharmacol Sci 9: 181-184, 1988.

MAXWELL AJ: Mechanisms of dysfunction of the nitric oxide pathway in vascular diseases. Nitric Oxide 6: 101-124, 2002.

MONCADA S, GRYGLEWSKI R, BUNTING S, VANE JR: An enzyme isolated from arteries transforms prostaglandin endoperoxides to an unstable substance that inhibits platelet aggregation. Nature 263: 663-665, 1976.

MORAWIETZ H, ROHRBACH S, RUECKSCHLOSS U, SCHELLENBERGER E, HAKIM K, ZERKOWSKI HR, KOJDA G, DARMER D, HOLTZ J: Increased cardiac endothelial nitric oxide synthase expression in patients taking angiotensin-converting enzyme inhibitor therapy. Eur J Clin Invest 36: 705-712, 2006.

MORENO H JR, PIOVESAN NATHAN L, PEREIRA COSTA SK, METZE K, ANTUNES E, ZATZ R, DE NUCCI G: Enalapril does not prevent the myocardial ischemia caused by the chronic inhibition of nitric oxide synthesis. Eur J Pharmacol 287: 93-96, 1995.

NOLL G, TSCHUDI M, NAVA E, LÜSCHER TF: Endothelium and high blood pressure. Int J Microcirc 17: 273-279, 1997.

PALMER RM, FERRIGE AG, MONCADA S: Nitric oxide release accounts for the biological activity of endotheliumderived relaxing factor. Nature 327: 524-526, 1987.

PARK YM, PARK MY, SUH YL, PARK JB: NAD(P)H oxidase inhibitor prevents blood pressure elevation and cardiovascular hypertrophy in aldosterone-infused rats. Biochem Biophys Res Commun 313: 812-817, 2004.

PECHÁŇOVÁ O: Contribution of captopril thiol group to the prevention of spontaneous hypertension Physiol Res 56 (Suppl 2): S41-S48, 2007.

PECHÁŇOVÁ O, BABÁL P: Activity of some adenine nucleotide degradation enzymes in human atherosclerotic aorta endothelium. Folia Biol (Praha) 39: 188-194, 1993.

PECHÁŇOVÁ O, BERNÁTOVÁ I: Effects of long term nitric oxide synthase inhibition in rat cardiovascular system (review). Exp Clin Cardiol 3: 151-157, 1998.

PECHÁŇOVÁ O, BERNÁTOVÁ I, PELOUCH V, ŠIMKO F: Protein remodelling of the heart in NO-deficient hypertension: the effect of captopril. J Mol Cell Cardiol 29: 3365-3374, 1997.

PECHÁŇOVÁ O, BERNÁTOVÁ I, PELOUCH V, BABÁL P: L-NAME-induced protein remodeling and fibrosis in the rat heart. Physiol Res 48: 353-362, 1999.

PECHÁŇOVÁ O, BERNÁTOVÁ I, BABÁL P, MARTINEZ MC, KYSELÁ S, ŠTVRTINA S, ANDRIANTSITOHAINA R: Red wine polyphenols prevent cardiovascular alterations in L-NAME-induced hypertension. J Hypertens 22: 1551-1559, 2004a. 
PECHÁŇOVÁ O, DOBEŠOVÁ Z, ČEJKA J, KUNEŠ J, ZICHA J: Vasoactive systems in L-NAME hypertension: the role of inducible nitric oxide synthase. J Hypertens 22: 167-173, 2004b.

PECHÁŇOVÁ O, MATUŠKOVÁ J, CAPÍKOVÁ D, JENDEKOVÁ L, PAULIS L, ŠIMKO $\mathrm{F}$ : Effect of spironolactone and captopril on nitric oxide and S-nitrosothiol formation in kidney of L-NAME-treated rats. Kidney Int 70: 170-176, 2006a.

PECHÁŇOVÁ O, REZZANI R, BABÁL P, BERNÁTOVÁ I, ANDRIANTSITOHAINA R: Beneficial effects of Provinols $^{\mathrm{TM}}$ : cardiovascular system and kidney. Physiol Res 55 (Suppl 1): S17-S30, $2006 \mathrm{~b}$.

PECHÁŇOVÁ O, ZICHA J, KOJŠOVÁ S, DOBEŠOVÁ Z, JENDEKOVÁ L, KUNEŠ J: Effect of chronic $\mathrm{N}$-acetylcysteine treatment on the development of spontaneous hypertension. Clin Sci 110: 235-242, 2006c.

PECHÁŇOVÁ O, ZICHA J, PAULIS L, ZENEBE W, DOBEŠOVÁ Z, KOJŠOVÁ S, JENDEKOVÁ L, SLÁDKOVÁ M, DOVINOVÁ I, ŠIMKO F, KUNEŠ J: The effect of N-acetylcysteine and melatonin in adult spontaneously hypertensive rats with established hypertension. Eur J Pharmacol 561: 129-136, 2007.

PÚZSEROVÁ A, CSIZMADIOVÁ Z, ANDRIANTSITOHAINA R, BERNÁTOVÁ I: Vascular effects of red wine polyphenols in chronic stress-exposed Wistar-Kyoto rats. Physiol Res 55 (Suppl 1): S39-S47, 2006.

PÚZSEROVÁ, CSIZMADIOVÁ Z, BERNÁTOVÁ I: Effect of blood pressure on L-NAME-sensitive component of relaxation in adult rats. Physiol Res $\mathbf{5 6}$ (Suppl 2): S77-S84, 2007.

RAUCHOVÁ H, PECHÁŇOVÁ O, KUNEŠ J, VOKURKOVÁ M, DOBEŠOVÁ Z, ZICHA J: Chronic $\mathrm{N}$-acetylcysteine administration prevents development of hypertension in L-NAME-treated rats: role of reactive oxygen species Hypertens Res 28: 475-482, 2005.

RUBANYI GM, BOTELHO LH: Endothelins. FASEB J 5: 2713-2720, 1991.

SANDERS PW, CHEN PY, GASTON RS, WARNOCK DG: L-arginine and nitric oxide in the regulation of blood pressure. In: Hypertension: Pathophysiology, Diagnosis, and Management, LARAGH JH, BRENNER BM (eds), Raven Press, New York, 1995, pp 1097-1108.

SASE K, MICHEL T: Expression and regulation of endothelial nitric oxide synthase. Trends Cardiovasc Med 7: 28-37, 1997.

SCHIFFRIN E: Beyond blood pressure: the endothelium and atherosclerosis progression. Am J Hypertens 15: 115S122S, 2002.

ŠIMKO F: Is NO the king? Pathophysiological benefit with uncertain clinical impact. Physiol Res 56 (Suppl 2): S1-S6, 2007.

ŠIMKO F, ŠIMKO J: Heart failure and angiotensin converting enzyme inhibition: problems and perspectives. Physiol Res 48: 1-8, 1999.

ŠIMKO F, PECHÁŇOVÁ O, BERNÁTOVÁ I, GVOZDJÁKOVÁ A, KUCHARSKÁ J, HULÍN I, BADA V, TURČÁNI M: Effect of captopril on the development of left ventricular hypertrophy in rabbits with aortic insufficiency. Physiol Res 46: 419-425, 1997.

ŠIMKO F, PECHÁŇOVÁ O, BERNÁTOVÁ I, HOLÉCYOVÁ A, ŠIMKO J, SOCHOROVÁ R: Captopril attenuates proteosynthesis in the aorta and decreases endothelaemia in rabbits with aortic insufficiency. Physiol Res 47: 103-107, 1998.

ŠIMKO F, LUPTÁK I, MATUŠKOVÁ J, BABÁL P, PECHÁŇOVÁ O, BERNÁTOVÁ I, HULÍN I: Heart remodeling in the hereditary hypertriglyceridemic rat: effect of captopril and nitric oxide deficiency. Ann NY Acad Sci 967: 454-462, 2002.

ŠIMKO F, PECHÁŇOVÁ O, BERNÁTOVÁ I, MATUŠKOVÁ J, LUPTÁK I: Experimental model of NO-deficient hypertension. In: Experimental Models of Diseases J. HOLZEROVÁ (ed), UK Bratislava, 2003, pp 68-71.

ŠIMKO F, LUPTÁK I, MATUŠKOVÁ J, KRAJČIROVIČOVÁ K, SUMBALOVÁ Z, KUCHARSKÁ J, GVOZDJÁKOVÁ A, ŠIMKO J, BABÁL P, PECHÁŇOVÁ O, BERNÁTOVÁ I: L-arginine fails to protect against myocardial remodelling in L-NAME-induced hypertension. Eur J Clin Invest 35: 362-368, 2005.

SLÁDKOVÁ M, KOJŠOVÁ S, JENDEKOVÁ L, PECHÁŇOVÁ O: Chronic and acute effects of different antihypertensive drugs on femoral artery relaxation of L-NAME hypertensive rats. Physiol Res $\mathbf{5 6}$ (Suppl 2): S85-S91, 2007.

STUEHR DJ: Mammalian nitric oxide synthases. Biochim Biophys Acta 1411: 217-230, 1999. 
TÖRÖK J, KOPRDOVÁ R, CEBOVÁ M, KUNEŠ J, KRISTEK F: Functional and structural pattern of arterial responses in hereditary hypertriglyceridemic and spontaneously hypertensive rats in early stage of experimental hypertension. Physiol Res 55 (Suppl 1): S65-S71, 2006.

TÖRÖK J, MATUŠKOVÁ J, PECHÁŇOVÁ O, KRAJČIROVIČOVÁ K, ŠIMKO F: Simvastatin, but not L-arginine, improves endothelial function of aorta in hereditary hypertriglyceridemic rats. Physiol Res $\mathbf{5 6}$ (Suppl 2): S33S40, 2007.

TOUYZ RM, SCHIFFRIN EL: Reactive oxygen species in vascular biology: implications in hypertension. Histochem Cell Biol 122: 339-352, 2004.

VANHOUTTE PM, FELETOU M, TADDEI S: Endothelium-dependent contractions in hypertension. Br J Pharmacol 144: 449-458, 2005.

ZHANG Y, HOGG N: S-Nitrosothiols: cellular formation and transport. Free Radic Biol Med 38: 831-838, 2005.

ZHOU MS, SCHULMAN IH, RAIJ L: Nitric oxide, angiotensin II, and hypertension. Semin Nephrol 24: 366-378, 2004.

ZICHA J, DOBEŠOVÁ Z, KUNEŠ J: Antihypertensive mechanisms of chronic captopril or N-acetylcysteine treatment in L-NAME hypertensive rats. Hypertens Res 29: 1021-1027, 2006a.

ZICHA J, PECHÁŇOVÁ O, ČAČANYIOVÁ S, CEBOVÁ M, KRISTEK F, TÖRÖK J, ŠIMKO F, DOBEŠOVÁ Z, KUNEŠ J: Hereditary hypertriglyceridemic rat: a suitable model of cardiovascular disease and metabolic syndrome? Physiol Res 55 (Suppl 1): S49-S63, 2006b.

\section{Corresponding author}

Ol'ga Pecháňová, Institute of Normal and Pathological Physiology, Slovak Academy of Sciences, Sienkiewiczova 1, 81371 Bratislava, Slovak Republic. Fax: +421-2-52968516. E-mail: olga.pechanova@savba.sk 